\title{
Selectivity and residual weed control of pre-emergent herbicides in soybean crop $^{1}$
}

\author{
Tiago Gazola *(D), Diego Munhoz Gomes ${ }^{4}$, Diego Belapart ${ }^{3}$, Márcio Furriela Dias ${ }^{2}$, \\ Caio Antonio Carbonari ${ }^{3}$, Edivaldo Domingues Velini ${ }^{3}$
}

10.1590/0034-737X202168030008

\begin{abstract}
The use of pre-emergent herbicides is important for the current agricultural production systems that present weeds resistant to herbicides. Considering the complexity of using these products, the objective of this work was to evaluate their selectivity and residual weed control in soybean crops and their effect on the weeds Amaranthus hybridus, Bidens pilosa, Digitaria insularis, Eleusine indica, and Euphorbia heterophylla. The herbicide selectivity experiments were conducted under field conditions in the 2017/18 and 2019/20 crop seasons and the herbicide efficacy experiments were conducted under greenhouse conditions. The herbicides s-metolachlor and flumioxazin can be applied on day of the soybean sowing without causing significant grain yield losses. Diclosulam and sulfentrazone are safe for soybean crops when applied at least 14 days before sowing. The herbicides used proved to be good options for weed management systems for soybean crops; flumioxazin and sulfentrazone were the herbicides that promoted the best control for all evaluated weed species and ensured a residual effect of at least 30 days.
\end{abstract}

Keywords: Diclosulam; flumioxazin; Glycine max; s-metolachlor; sulfentrazone; weeds.

\section{INTRODUCTION}

The competition of soybean (Glycine max) plants with weeds for environmental resources (water, light, and nutrients) is frequently reported as a direct cause of grain yield losses, especially when they are not adequately controlled, decreasing grain yield in up to $82 \%$ (Silva $e t$ al., 2008).

The most used method for weed manage is the use of herbicides. Brazilian producers consumed US $\$ 10.5$ billion in pesticides in 2018; $33 \%$ of them were herbicides (Sindiveg, 2018). The resistance of weeds to herbicides has contributed to this situation; currently, there are 51 reports of herbicideresistant weeds in Brazil (Heap, 2020), which have significantly increased production costs. The estimated annual cost with herbicide-resistant weeds in soybean crops may reach US $\$ 2.7$ billion when production losses due this competition are considered (Adegas et al., 2017).
In this context, two new technologies will be available in the next years for soybean, Enlist ${ }^{\mathrm{TM}}$ (Corteva, Wilmington, USA) and Intacta 2 Xtend $^{\circledR}$ (Bayer, Leverkusen, Germany). Soybean plants with Enlist ${ }^{\mathrm{TM}}$ are tolerant to 2,4-D choline salt, glyphosate, and ammonium glufosinate. Soybean plants with Intacta $2 \mathrm{Xtend}^{\circledR}$ are tolerant to glyphosate and Dicamba herbicides. However, these new technologies should be adoption with caution to mitigate the evolution of weeds resistant to these herbicides and avoid management errors that have been made with the use glyphosate in the past.

Rotation of herbicides with different mechanisms of action is a practice that may preserve these technologies. Pre-emergent residual herbicides that were once widely used fit to this system and should be reintroduced; however, when these products contact the soil, they may undergo complex retentions, transformations, and transport

\footnotetext{
Submitted on April 17 $7^{\text {th }}, 2020$ and accepted on December $3^{\text {rd }}, 2020$.

${ }^{1}$ The manuscript was funded by Coordenação de Aperfeiçoamento de Pessoal de Nível Superior (CAPES).

2 Universidade Estadual Paulista "Júlio de Mesquita Filho", Departamento de Proteção Vegetal, Botucatu, São Paulo, Brazil. tiago-gazola@hotmail.com; marciofdiass@outlook.com

${ }^{3}$ Universidade Estadual Paulista "Júlio de Mesquita Filho", Departamento de Produção e Melhoramento Vegetal, Botucatu, São Paulo, Brazil. diegobelapartt@hotmail.com; carbonari@fca.unesp.br; velini@uol.com.br

${ }^{4}$ Universidade Estadual Paulista “Júlio de Mesquita Filho”, Departamento de Engenharia Florestal, Botucatu, São Paulo, Brazil. diegomgomes77@gmail.com

*Corresponding author: tiago-gazola@hotmail.com
} 
processes that make their activity dependent on the product physicochemical characteristics, soil attributes, climate conditions, crop system, and the interaction between these factors (Oliveira Jr et al., 2011). In addition, tolerant soybean cultivars may respond differently to stress caused by herbicides due to genotypic differences (Lima et al., 2011).

Thus, the selectivity and effectiveness of residual herbicides need to be better understood in current production systems, considering mainly the adopted crop system and the new available soybean cultivars. Therefore, the objective of the present work was to evaluate the selectivity and residual weed control of pre-emergent herbicides applied before and at the sowing of soybean crops.

\section{MATERIAL AND METHODS}

The herbicide selectivity experiments were conducted under field conditions in Botucatu, state of São Paulo, Brazil (2250'31.5'S, 48²5'26.7' W, and 785 m altitude). The soil of the area was a dystrophic red Nitisol (Nitossolo Vermelho distrófico); its physical and chemical characteristics are described in Table 1. The herbicide efficacy experiments were conducted in a greenhouse in the same location and soil, which was sieved and crushed to be used as a substrate.

The climate of the region is Cwa, mesothermal, with rainy summer and dry winter, according to the Köppen classification, presenting mean temperature in the coldest month below $17^{\circ} \mathrm{C}$ and mean temperature in the warmest month above $22^{\circ} \mathrm{C}$ (Cunha \& Martins, 2009). The climatic conditions throughout the experiments are shown in Figure 1. A sprinkler irrigation system was used according to the needs of the crops, which occurred only once in the 2018/19 crop season; thus, the crops were conducted practically in rainfed conditions.

\section{Selectivity and application of pre-emergent herbicides to the soybean crops}

Two experiments were conducted, in the 2017/2018 and $2018 / 2019$ crop seasons. The area was fallow, but was previously subjected to harrowing and application of dolomitic limestone ( $2 \mathrm{Mg} \mathrm{ha}^{-1}$ ) two months before the soybean sowing for the first experiment. Twenty days before the implementation of the experiments, the whole area was desiccated using glyphosate at $6 \mathrm{~L} \mathrm{ha}^{-1}$ of the commercial product (Roundup DI ${ }^{\circledR}$, Monsanto, St. Louis, United States) and 2,4-D at $1.5 \mathrm{~L} \mathrm{ha}^{-1}$ of the commercial product (DMA ${ }^{\circledR} 806 \mathrm{BR}$; Dow AgroSciences, Indianapolis, USA) with a flow rate of $200 \mathrm{~L} \mathrm{ha}^{-1}$.

A randomized block experimental design with 4 replications was used, in a $9 \times 3$ factorial arrangement, consisted of 9 treatments with and without herbicides and 3 application times, 14, 7, and 0 days before the soybean planting (DBSP), the latter was carried out subsequently to the soybean sowing. The application times were defined based on agronomical applicability, considering the climate conditions of the period between crop seasons and the average residual effect of the herbicides. The rate used for each herbicide was that recommended in the product label to assess the dynamics of the products without the need for adjusts, which explains the different application times adopted. Each experimental unit consisted of an area of of $15.75 \mathrm{~m}^{2}(5.00 \times 3.15 \mathrm{~m})$. The treatments used are described in Table 2.

The herbicides were applied using a $\mathrm{CO}_{2}$-pressurized backpack sprayer equipped with six flat jet nozzles (TTI 110015 ; Teejet ${ }^{\circledR}$, Wheaton, USA), spaced $0.50 \mathrm{~m}$ apart, set to a pressure of $300 \mathrm{kPa}$ and a flow rate of $180 \mathrm{~L} \mathrm{ha}^{-1}$. The air temperature, relative air humidity and wind speed at the time of herbicide applications were, respectively, $26.5^{\circ} \mathrm{C}$, $48 \%$, and $5.4 \mathrm{~km} \mathrm{~h}^{-1}$ (14 DBSP); $24.5^{\circ} \mathrm{C}, 52 \%$, and $5.0 \mathrm{~km} \mathrm{~h}^{-}$ ${ }^{1}$ (1-7 DBSP); $28^{\circ} \mathrm{C}, 44 \%, 4.4 . \mathrm{km} \mathrm{h}^{-1}$ (0 DBSP) for Experiment 1; and $24.5^{\circ} \mathrm{C}, 57 \%, 6.4 . \mathrm{km} \mathrm{h}^{-1}$ (2-14 DBSP); $22.5^{\circ} \mathrm{C}, 61 \%$, and 7.0. $\mathrm{km} \mathrm{h}^{-1}$ (2-7 DBSP); $23.5^{\circ} \mathrm{C}, 61 \%$, and $7.2 \mathrm{~km} \mathrm{~h}^{-1}(0$ DBSP) for Experiment 2.

The soybean seeds were treated at the sowing days with products consisted of fipronil $\left(713 \mathrm{~g} \mathrm{~L}^{-1}\right)+$ pyraclostrobin $\left(25 \mathrm{~g} \mathrm{~L}^{-1}\right)+$ thiophanate-methyl $\left(225 \mathrm{~g} \mathrm{~L}^{-1}\right)$ (Standak Top ${ }^{\circledR}$; Basf, Ludwigshafen, Germany) and Cobalt $15.6 \mathrm{~g} \mathrm{~L}^{-1}+$ Molybdenum $234 \mathrm{~g} \mathrm{~L}^{-1}$ (Attivare ${ }^{\circledR}$ Multi Top; AgriVitta, Matão, Brazil), both at the rate of $200 \mathrm{~mL}$ of the

Table 1: Physical and chemical characteristics of the 0-20 cm layer of the soil of the experimental area in the 2017/18 soybean crop season

\begin{tabular}{|c|c|c|c|c|c|c|c|c|c|c|c|}
\hline \multirow{2}{*}{$\begin{array}{l}\text { Organic matter } \\
\mathrm{g} \mathrm{dm}^{-3}\end{array}$} & \multirow{2}{*}{$\frac{\mathrm{pH}}{\mathrm{CaCl}_{2}}$} & $\mathbf{P}_{\text {resin }}$ & $\mathbf{S}$ & $\mathbf{C a}$ & Mg & $\mathbf{K}$ & $\mathbf{H}+\mathbf{A l}$ & SB & $\mathbf{A l}^{+3}$ & CEC & BS \\
\hline & & \multicolumn{2}{|c|}{$\mathrm{mg} \mathrm{dm}^{-3}$} & \multicolumn{8}{|c|}{$\mathrm{mmol}_{\mathrm{c}} \mathrm{dm}^{-3}$} \\
\hline 25 & 4.7 & 39 & 11 & 25 & 10 & 2.3 & 18 & 38 & 0 & 90 & 66 \\
\hline \multicolumn{12}{|c|}{ Granulometry $\left(\mathrm{g} \mathrm{Kg}^{-1}\right)$} \\
\hline Coarse sand & \multicolumn{3}{|c|}{ Fine sand } & Total sand & & \multicolumn{2}{|l|}{ Clay } & \multicolumn{2}{|c|}{ Silt } & \multicolumn{2}{|c|}{ Texture class } \\
\hline 51 & \multicolumn{3}{|c|}{152} & 203 & & \multicolumn{2}{|l|}{507} & \multicolumn{2}{|c|}{290} & \multicolumn{2}{|c|}{ Clayey } \\
\hline
\end{tabular}

$\mathrm{SB}=$ sum of bases; $\mathrm{CEC}=$ cation exchange capacity; $\mathrm{BS}=$ base saturation

Rev. Ceres, Viçosa, v. 68, n.3, p. 219-229, may/jun, 2021 
commercial product per $100 \mathrm{~kg}$ of seeds. Soybean seeds of the cultivar M6410IPRO (Monsoy, São Paulo, Brazil) were sowed on November 1, 2017 for Experiment 1, and on November 27, 2018 for Experiment 2. The plots were sowed with 16.4 seeds $\mathrm{m}^{-1}$ in seven 5 -meter rows spaced $0.45 \mathrm{~m}$ apart. Soil fertilizers were applied at soybean sowing, using $250 \mathrm{~kg} \mathrm{ha}^{-1}$ of the N-P-K formulation 02-20-20; topdressing consisted of application of $60 \mathrm{~kg} \mathrm{ha}^{-1}$ of $\mathrm{KCl}$ at 35 days after sowing.

Weed control at post-emergence of the soybean crops was carried out in the whole area at 15 days after emergence, using glyphosate (Roundup DI ${ }^{\circledR}$, Monsanto, St. Louis, United States) at $6 \mathrm{~L}$ of the commercial product per hectare, clethodim $\left(240 \mathrm{~g} \mathrm{~L}^{-1}\right)\left(\right.$ Select $240 \mathrm{EC}^{\circledR}$; UPL Ltd, Mumbai, India) at $0.45 \mathrm{~L}$ of the commercial product per hectare), and the adjuvant (Lanzar ${ }^{\circledR}$; UPL Ltd, Mumbai, India) $0.5 \% \mathrm{v} \mathrm{v}$ ${ }^{1}$, at a flow rate of $200 \mathrm{~L} \mathrm{ha}^{-1}$. Pest and disease control were carried out according to technical recommendations for the crop in the region. After the crop harvested in the first experiment, the area was grown with corn to avoid fallow until the soybean sowing for the second experiment. The corn crop was grown following the technical recommendations of fertilization and phytosanitary management used for the crop in the region. The area was previously desiccated for the sowing of the second soybean crop, using glyphosate (Roundup DI ${ }^{\circledR}$, Monsanto, St. Louis, United States) at $6 \mathrm{~L}$ of the commercial product per hectare, at 14 DBSP, when the herbicide treatments were applied.

The heights of the soybean plant at 20 days after emergence (DAE), and at 120 DAE (harvest time), when the plant stand, number of pods, 1,000 grain weight $(1000 \mathrm{GW})$ and grain yield were also evaluated. Plant height was evaluated considering 15 plants per plot, measured from the stem base to the last trifoliate leaf insertion. The plant stand was evaluate considering the number of plants in 4 linear meters choose randomly in each plot. The number of pods was evaluated considering total number of pods of 10 randomly chosen plants in each plot. The $1000 \mathrm{GW}$ was evaluated after harvesting; 1,000 seeds from each plot was measured for moisture content using a moisture meter (G929; Gehaka, São Paulo, Brazil) and weighed on a precision $(0.0001 \mathrm{~g})$ balance. Grain yield was evaluated considering the three central rows in the central four meters of each plot, the seed was corrected to $13 \%$ and then weighed.

The results were subjected to analysis of variance by the F test and the means compared by the Scott Knott test at $p<0.05$.

\section{Residual weed control of pre-emergent herbicides recommended for soybean crops}

Two experiments were conducted in a greenhouse in 2018 and 2019. The species Amaranthus hybridus, Bidens pilosa, Digitaria insularis, Eleusine indica, and Euphorbia heterophylla were evaluated. The experimental units consisted of 2-liter pots with a soil, whose physical and chemical characteristics are described in Table 1. Two weed species were sown in each pot to avoid competition between plants. The amount of seeds of each weed was determined by their weights, based on a previous germination test, to obtain 15 plants per species.

The residual weed control of the herbicides was evaluated after herbicide applications at 30, 20, 10, and 0 days before the weed sowing. On day 0 , the last herbicide application was carried out and all plots were sowed with seeds of each weed to a depth of $1 \mathrm{~cm}$ to cause little soil disturbance. The sowing was carried out before the application of herbicide to plots with treatments applied at day 0 . The methodology used enabled to assess the residual weed control period at $0,10,20$ and 30 days after application of the herbicide to the soil.
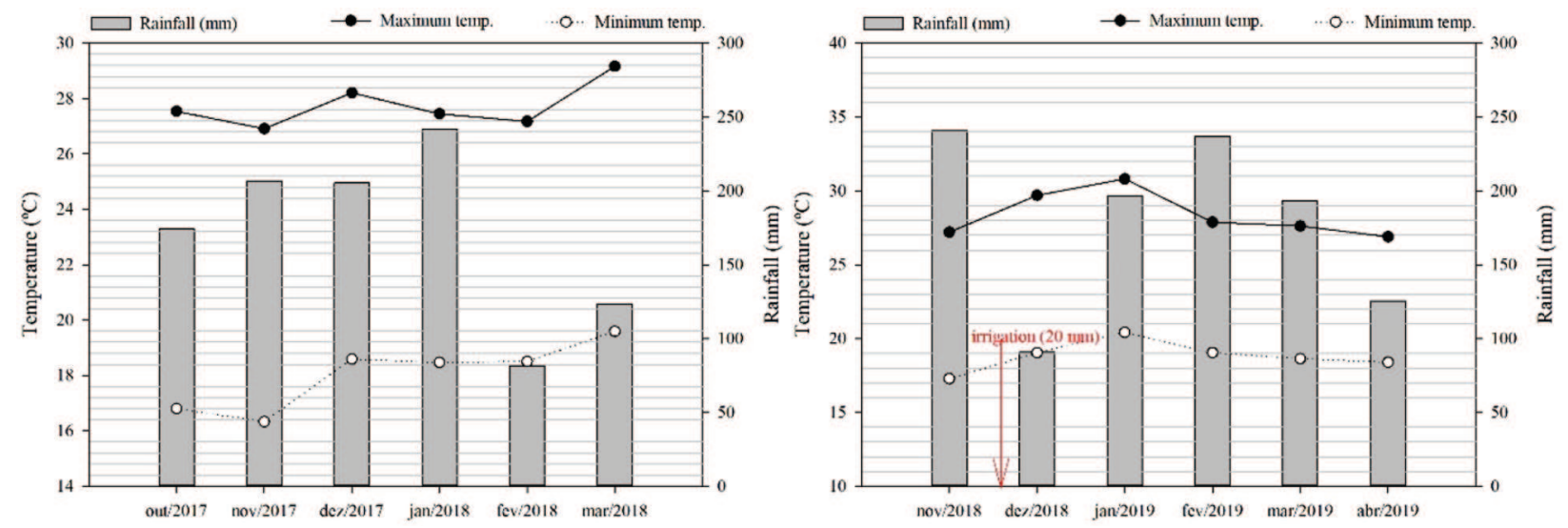

Figure 1: Climate conditions throughout the experiments. Climate data were acquired from a weather station installed in the experimental area (São Paulo State University, Faculty of Agronomic Sciences, Botucatu, SP, Brazil). Rainfall data include the irrigations applied. 
A completely randomized experimental design with 4 replications was used, in a $4 \times 4$ factorial arrangement consisted of 4 herbicides and 4 application times. The herbicides and rates used are described in Table 2 .

The treatments were applied using a stationary sprayer with a metal structure supporting 2-meter a spray boom which run through 6 meters with the aid of an electric motor with a frequency modulator that controls the working speed. The spray boom was equipped with extended range flat spray tips (XR 11002 VS Teejet ${ }^{\circledR}$, Wheaton, USA) spaced $0.5 \mathrm{~m}$ apart and positioned at $0.5 \mathrm{~m}$ above the experimental units, set to a working pressure of $196.13 \mathrm{kPa}$ and a speed of $3.6 \mathrm{~km} \mathrm{~h}^{-1}$, resulting in a flow rate of $200 \mathrm{~L} \mathrm{ha}^{-1}$. The mean air temperatures and relative air humidity at the time of application were $29.5^{\circ} \mathrm{C}$ and $51 \%$, respectively, for Experiment 1 , and $31.4^{\circ} \mathrm{C}$ and $49 \%$, respectively, for Experiment 2.

The plots were subjected to simulated field rainfall conditions, following the methodology proposed by Raimondi et al. (2010) with adaptations: the plots were irrigated with $10 \mathrm{~mm}$ water depth at 24 hours before the application of herbicide in each season (30, 20, 10 and 0 days before weed sowing), and again the plots that had already received the herbicide application at the time of application in the next season. At the end of the herbicide applications and weed sowing, irrigations with $10 \mathrm{~mm}$ water depth were performed whenever necessary.

The number of live plants and shoot dry weight of each weed species was evaluated at 30 days after weed sowing. The shoot dry weight was obtained by drying the plants' shoots in a forced air-circulation oven at $60^{\circ} \mathrm{C}$ until constant weight, which was measured in a precision $(0.0001$ g) balance. The obtained data were transformed into percentages, using the number of live plants and shoot dry weight found in control plots not treated with herbicides as reference. The control percentage was obtained using the average between the percentage of the number of live plants and the shoot dry weight.

The results were subjected to analysis of variance by the F test and the means compared by the Tukey' test at $p<0.05$.

\section{RESULTS AND DISCUSSION}

\section{Selectivity and application of pre-emergent herbicides to the soybean crops}

Most soybean farmers are concerned with the use of herbicides with residual effect at the soybean pre-planting, mainly due to the slower initial crop start-up caused by them, which decreases the grain yield. No significant decreases in soybean plant height was found at 20 and 120 days after emergence (DAE) in the 2017/18 and 2018/ 2019 crop seasons, except for the treatment with the herbicide sulfentrazone applied at the soybean planting time, 0 days before the soybean planting (DBSP) in the 2017/18 crop season (Table 3).

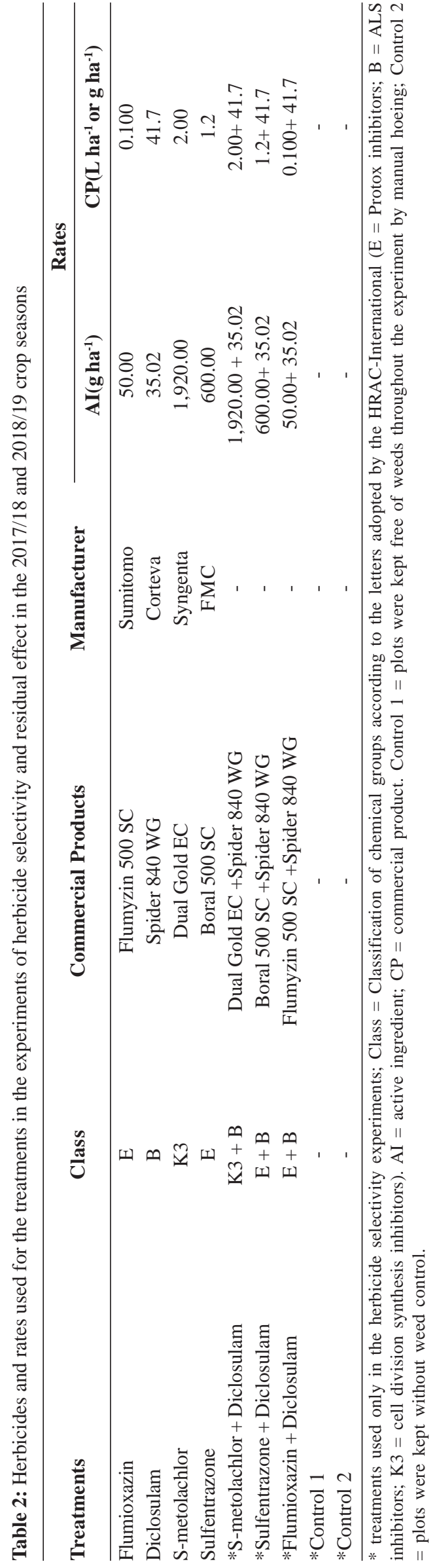




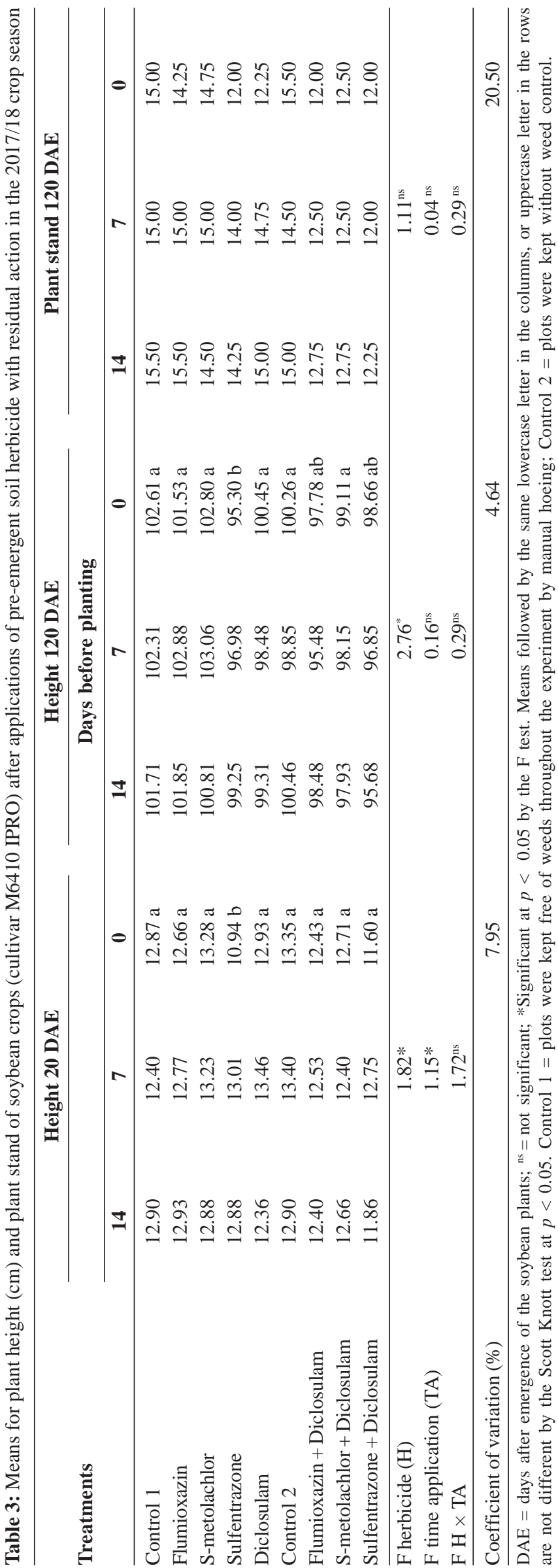

Sulfentrazone, diclosulam, and all combinations of herbicides resulted in the lowest plant heights at 0 DBSP, at 120 DAE, in the $2018 / 19$ crop season, presenting plants with less than $80 \mathrm{~cm}$, whereas the soybean plant heights were between 96.88 and 101.28 $\mathrm{cm}$ in the control treatments (Table 4).

The treatments had no significant differences for plant stand at harvest (120 DAE) in the 2017/18 crop season; however, the application of combinations of residual herbicides (flumioxazin + diclosulam, smetolachlor + diclosulam, and sulfentrazone + diclosulam), sulfentrazone, and diclosulam herbicides had mean plant stand of $20 \%$ lower than the plants in the control treatments (Table 3). This difference was $13 \%$ in the 2018/19 crop season (Table 4).

Roman et al. (2000) found lower plant heights in soybean plants treated with diclosulam and sulfentrazone at 4 days after sowing in a $44 \%$ clay soil, when compared to the control, but no reduction in grain yield; they explained that the plants may have metabolized the herbicides and recovered from the initial stress caused by the herbicides. A rapid metabolism underlies the soybean tolerance to sulfentrazone and ALS inhibitor herbicides such as diclosulam (Kent et al., 1988; Dayan et al., 1997). However, in the present study, the soybean plants did not recover from the effects of these herbicides at 0 DBSP and they decreased the grain yield (Table 5 and 6), which may be explained by the different tolerance of soybean cultivars because of their genotypic differences (Lima et al., 2011).

Proper cropping results in greater light uptake by the leaves, faster initial development, increased uptake and use of soil nutrients and, consequently, more vigorous plants. This allows crops to be more competitive and occupy the soil more quickly, facilitating the closure of spaces between planting rows, ensuring greater and faster shading of the soil surface, and thereby limiting the development of weeds (Oliveira Jr et al., 2011). Therefore, it is essential that pre-emergence herbicides do not interfere with the speed and quality of crop establishment, and allow the plants to express their full production potential. In this context, the application of diclosulam, sulfentrazone, s-metolachlor + diclosulam, flumioxazin + diclosulam, and sulfentrazone + diclosulam at the soybean sowing day should be avoided.

No significant differences were found in number of pods when the herbicides were applied at 14,7 , and 0 DBSP in the 2017/18 and 2018/19 crop seasons (Tables 5 and 6). In the 2017/18 crop season, all herbicide combinations presented lower 1,000 grain weight $(1000 \mathrm{GW})$ than the controls, regardless of the 


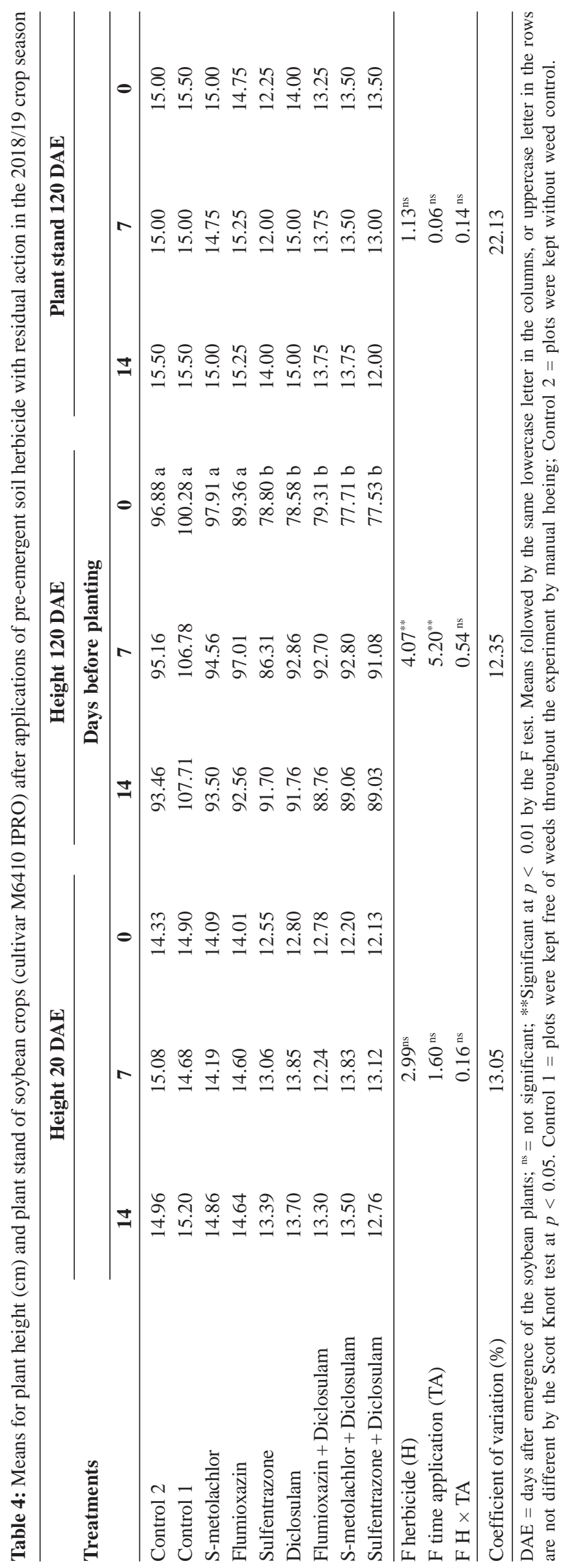

application time; at 0 DBSP the herbicides diclosulam and sulfentrazone also presented lower 1000GW than the controls, which decreased grain yield (Table 5). In the 2018/19 crop season, no differences in 1000GW was found at 14 DBSP, and at 7 DBSP and 0 DBSP, only the s-metolachlor and flumioxazin herbicides did not significantly decreased $1000 \mathrm{GW}$, which resulted in higher grain yield when compared to the other herbicide treatments (Table 6).

In the $2017 / 18$ crop season, the herbicides smetolachlor, flumioxazin, diclosulam and sulfentrazone applied at 14 and 7 DBSP were selective to the soybean cultivar used, showing no statistical difference in grain yield when compared to the controls, whereas the herbicide combinations were not selective to the crop, regardless of the application time (Table 5). S-metolachlor and Flumioxazin were the only herbicides selective to the soybean crop at 0 DBSP, resulting in grain yields of 5.023 and $4.715 \mathrm{~kg} \mathrm{ha}^{-1}$, respectively (Table 5).

In the 2018/19 crop season, all treatments were selective to the soybean crop at 14 DBSP; however, the herbicide combinations resulted in lower grain yields than the controls, with mean of $532 \mathrm{~kg} \mathrm{ha}^{-1}$ (Table 6). S-metolachlor and flumioxazin were the only selective herbicides for the soybean crop at 7 and 0 DBSP, resulting in yields of 5.019 and $4.778 \mathrm{~kg} \mathrm{ha}^{-1}$ and 4.740 and $4.693 \mathrm{~kg} \mathrm{ha}^{-1}$, respectively (Table 6).

No significant difference was found between the controls and the other treatments (Tables 5 and 6); therefore, the weeds had no differences in grain yield. Thus, differences in grain yield were related to the application of herbicides and their selectivity to the soybean crops.

The selectivity of the herbicides flumioxazin, sulfentrazone, s-metolachlor, and diclosulam were also evaluated in experiments conducted by Sanchotene $e t$ al. (2017), who found that these products were selective to soybean crops when applied to soils with $12 \%$ clay, at one day after sowing. Matte et al. (2019) reported no soybean grain yield losses after application of diclosulam at the soybean sowing day in a loamy soil (68\% clay). Walsh et al. (2015) evaluated the effect of sulfentrazone on soybean crops and found no injuries and grain yield losses after application of sulfentrazone subsequently to the soybean sowing in several areas in Canada. Neto et al. (2010) found no soybean grain yield losses after soil application of smetolachlor combined with glyphosate at the Soybean V1 stage in a $68 \%$ clay soil. Mahoney et al. (2014) evaluated the effects of flumioxazin on soybean crops in different locations and soil textures in Canada and found that flumioxazin applied at up to 10 days before the soybean planting result in grain yield losses. 


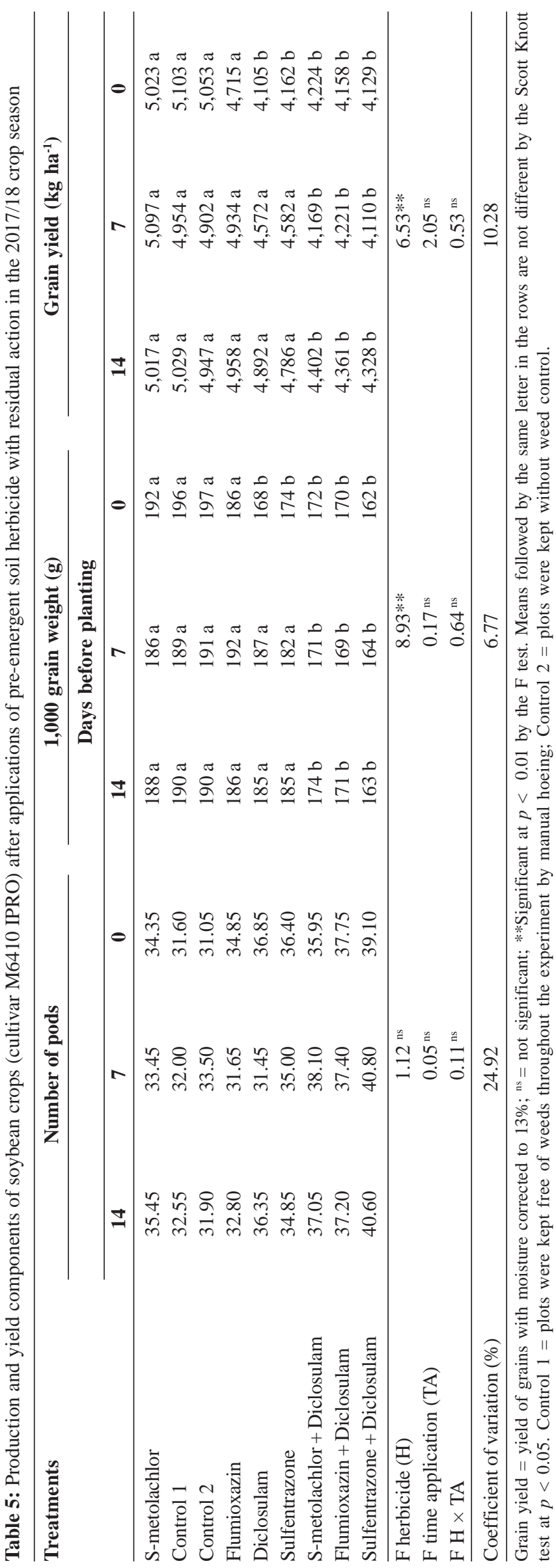

The variation in the results found in the present study under field conditions occurred because of the correlation between the dynamics of the of preemergent herbicides and the local climatic and edaphic conditions (Oliveira Jr et al., 2011) and genotype used (Lima et al., 2011). Considering the safety and efficacy of these products, the ideal is that continuous local studies provide information about the use of such products for soybean crops in different agricultural regions.

Weed management before the soybean sowing in no-tillage system is essential for a good crop development; it provides an early development without interference by competition with weeds, high operational yield, and sowing uniformity (Constantin et al,. 2007). In this context, the adoption of residual herbicides is essential to eliminate weeds emerging before the soybean sowing. In addition, the use of these products enables the rotation of mechanisms of action-which is essential to prevent the evolution of weed resistance to herbicides-and improves the action of post-emergence herbicide by reducing weed emergence, delaying weed development and, consequently, allowing these products to act on weeds at initial developmental stages.

However, this first application between crop season depends on the onset of rainfall before the soybean sowing; according to Monquero (2014), soil water content is related to the the efficiency of virtually all herbicides. The efficiency of most of them is hindered when they are applied to dry soils, especially at preemergence, when soil moisture is the main factor for their activation and dispersal to weed seeds.

The efficiency of these products usually decreases as the time between application and rainfall or irrigation increases. For example, according to Carbonari et al. (2009), the control levels of the herbicide flumioxazin tend to decrease for some weed species when the time between application and rainfall is longer than 30 days, and this can be attributed to the degradation of the product in the soil.

\section{Control period with recommended pre- emergent soybean herbicides}

Regarding the efficacy of herbicides in the main weed species in soybean, s-metolachlor was highly efficient for Digitaria insularis and Eleusine indica, with almost $100 \%$ control and residual effect throughout a period of at least 30 days (Figure 2a). The control of Bidens pilosa was also effective, with a residual effect of $80 \%$ control up to 30 days. Although the control of Amaranthus hybridus was also effective up to 30 days, the residual effect decreased with time; the control 


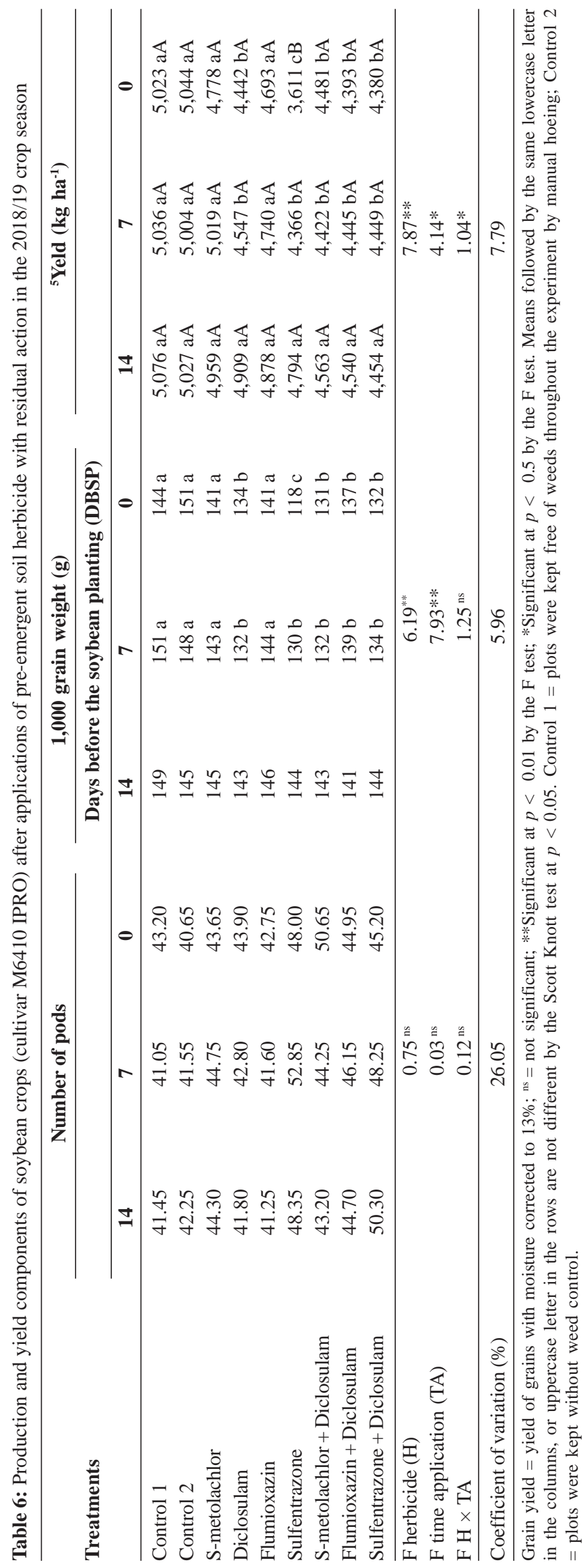

was $99 \%$ at 0 days before weed sowing (DBS) and $83 \%$ at 30 DBS (Figure 2a).

The herbicide Flumioxazin was also highly effective for the control of D. insularis, B. pilosa, $E$. indica, and $A$. hybridus, with more than $90 \%$ control up to 30 days after application (Figure 2b). Although this herbicide was also highly effective for Euphorbia heterophylla, it showed a slight decrease in the period of residual effect, with approximately $80 \%$ control at 30 DBS (Figure 2b).

The herbicide diclosulam was highly effective for the control of $D$. insularis, with periods of residual effect of up to 10 days after its application. It showed approximately $80 \%$ control of B. pilosa, with a residual effect of at least 30 days, and was highly effective for the control of $E$. indica up to 10 days. Diclosulam showed efficient control of A. hybridus, but no significant residual effect was observed. Diclosulam was not effective for the control of $E$. heterophylla (Figure 2c).

The herbicide sulfentrazone was highly effective for all species evaluated, maintaining approximately $100 \%$ control for at least 30 days after its application (Figure 2d).

Flumioxazin, s-metolachlor, diclosulam, and sulfentrazone are commonly used herbicides for soybean crops. These herbicides have been shown efficient control of several weeds when applied at pre-emergence and at commercial rate: Jaremtchuk et al. (2009) found high control levels of Alternanthera tenella, Digitaria horizontalis, D. insularis, E. heterophylla and Sida latifolia for flumioxazin; Magalhães et al. (2012), Reddy et al. (2012), and Correia et al. (2013) found efficient control of Ipomoea hederifolia, Ipomoea quamoclit, Urochloa decumbens and Amaranthus palmeri for sulfentrazone; Lopes Ovejero et al. (2013) and Mancuso et al. (2016) found efficient control of $B$. pilosa, Amaranthus viridis, Raphanus raphanistrum and I. hederifolia for diclosulam; and Silva et al. (2014) found efficient control of Amaranthus spinosus, Digitaria bicornis, and Commellina benghalensis for s-metolachlor.

The time that weeds can coexist with the soybean crop without reducing grain yield is called period before interference (PBI) (Pitelli, 1985). Considering the weed management, this time is the most important in the crop cycle, since grain yield is significantly affected after this time (Meschede $e t$ al. 2004).

The use of new cultivars of indeterminate habit and drought periods at the initial developmental stages of the crop have decreased the PBI and 
increased the time for canopy closure, thus increasing the total period of prevention and interference (PTPI) and the period for weeds to grow in the interrows, which decreases the soybean grain yield.

Therefore, the use of herbicides with residual effect is effective to minimize weed competition, increase the PBI, improve the crop canopy closure, and avoid production losses. The critical period for soybean crops is between 10 and 36 days after emergence, varying according to the cultivar, soil type, and weed species and infestation level (Silva et al., 2011). The choosing of herbicides should prioritize the selectivity to the crop, climate conditions, and the weed developmental stage. Therefore, the ideal is that the crop be sowed in a weed-free field, and the weed management starts in the period between crop seasons, including the use of residual herbicides.

Monquero et al. (2013) evaluated applications of diclosulam to a clayey soil and detected the herbicide in the soil up to 90 days after its application. in Brazilian soils, sulfentrazone has an average half-life of 180 days (Rodrigues \& Almeida, 2011); s-metolachlor has an average half-life of 15 to 50 days (Rodrigues \& Almeida, 2011); and flumioxazin has an average half-life in 21 days (Muller et al., 2017). Thus, the use of these herbicides can, in general, decrease weed interference at the initial crop developmental stages and contribute to a more effective and earlier canopy closure of soybean crops (Oliveira Neto et al., 2013).

The herbicides used presented excellent residual weed control up to 30 days (Figures 2a, 2b, 2c and 2d) and the crops were free of weeds until at least 16 days after weed sowing, despite the herbicides were applied at 14 DBSP. This time would be enough for the crop to develop in a clear field, requiring only a single post-emergence application to suppress weed development during the critical period. According to Velini et al. (1993), herbicide selectivity is the herbicide's ability to eliminate weeds in a crop field without reducing the grain yield and quality of the crop; thus, the herbicides flumioxazin, s-metolachlor, sulfentrazone, and diclosulam were selective to soybean crops of the cultivar M6410 IPRO.

One of the main issues related to weed management in agricultural crops in the world is the constant emergence of new cases of herbicide-resistant biotypes (Beckie, 2011). In this context, the use of residual herbicides is important for minimizing the evolution of resistant weeds by rotating mechanisms of action and suppressing the emergence of various weeds (López-Ovejero et al., 2013). Moreover, the herbicides flumioxazin, s-metolachlor, diclosulam, and sulfentrazone have proved to be excellent tools for the control of weed species and can be used safely and effectively in weed managements for soybean crops, when properly used.
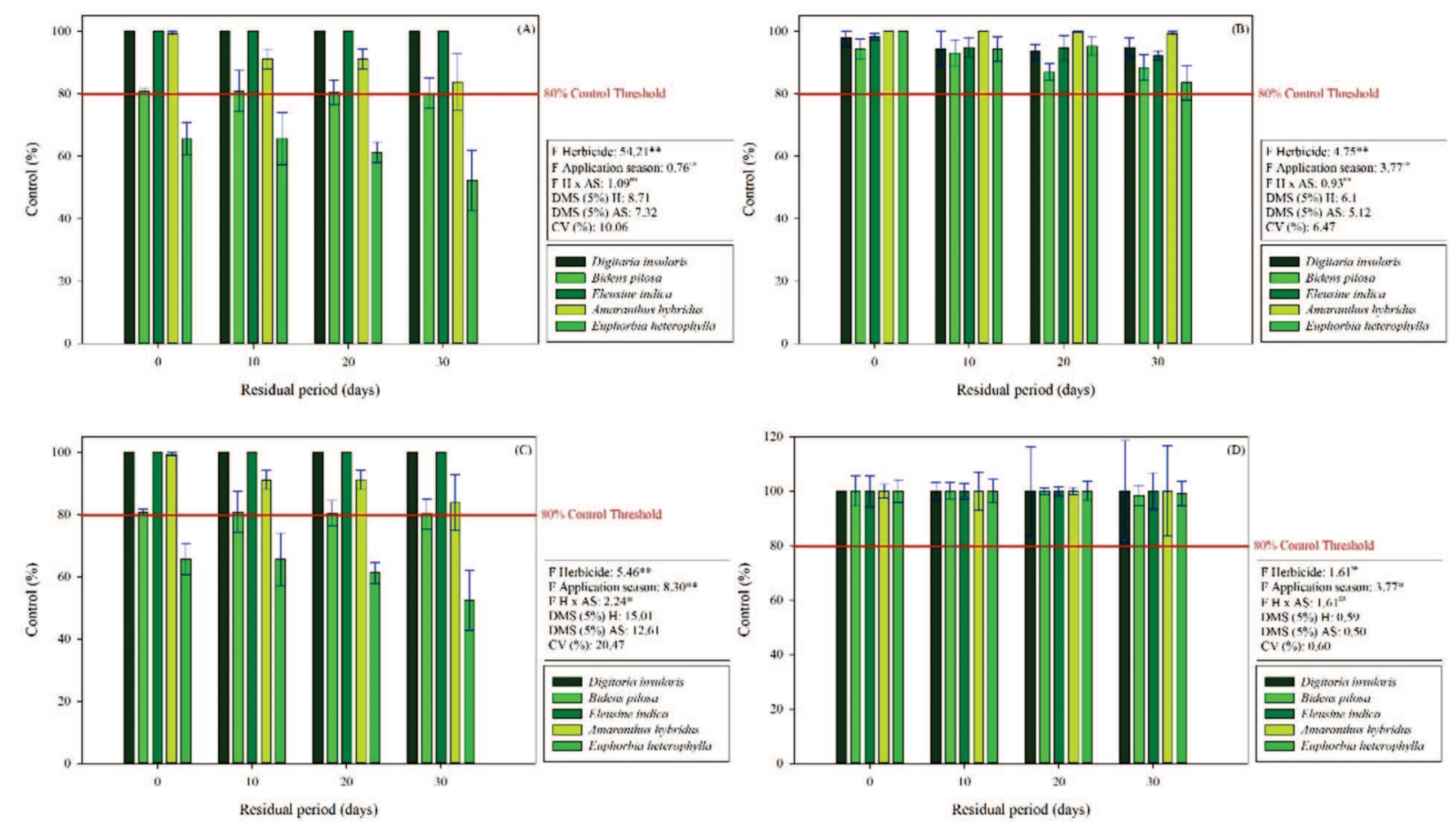

${ }^{\mathrm{ns}}=$ not significant; $* *=$ significant at $p<0.01 ; *$ significant at $p<0.05$ by the $\mathrm{F}$ test. MSD = minimum significant difference; CV $=$ coefficient of variation. Means of the two experiments.

Figure 2: Period of residual effect with efficacy for the herbicides S-metolachlor (A), flumioxazin (B), diclosulam (C), and sulfentrazone (D) against the weed species Digitaria insularis, Bidens pilosa, Eleusine indica, Amaranthus hybridus, and Euphorbia heterophylla. 


\section{CONCLUSION}

The herbicides flumioxazin and s-metolachlor can be applied on day of the soybean sowing, and diclosulam and sulfentrazone can be applied at least fourteen days before the sowing to avoid damages to soybean plants of the cultivar M6410 IPRO.

All herbicides applied proved to be excellent tools for the management of difficult-to-control weeds in the period between crop seasons. Flumioxazin and sulfentrazone were the most effective herbicides for the control of all weed species evaluated.

\section{ACKNOWLEDGEMENTS, FINANCIAL SUPPORT AND FULL DISCLOSURE}

The authors thank the Brazilian Coordination for the Improvement of Higher Education Personnel (CAPES); and the Faculty of Agronomic Sciences of the São Paulo State University, Botucatu campus (UNESP - FCA); all staff of the Center for Advanced Research in Weed Science (NUPAM); the Corteva Agriscience; FMC Corporation; Sumitomo Chemical; and Syngenta. The authors declared no conflicts of interest.

\section{REFERENCES}

Adegas FS, Vargas L, Gazziero DLP \& Karam D (2017) Impacto econômico da resistência de plantas daninhas a herbicidas no Brasil. Londrina, Embrapa Soja. 11p. (Circular, 132).

Beckie HJ (2011) Herbicide-resistant weed management: focus on glyphosate. Pest Management Science, 67:1037-104.

Carbonari CA, Gomes GLGC \& Velini ED (2009) Effects of flumioxazin permanence period in soil and in corn and oat mulch on weed control efficacy. Revista Brasileira de Herbicidas, $8: 85-95$.

Constantin J, Oliveira Jr RS, Cavalieri SD, Arantes JGZ, Alonso DG, Roso AC \& Costa JM (2007) Interação entre sistemas de manejo e de controle de plantas daninhas em pós-emergência afetando o desenvolvimento e a produtividade do milho. Planta Daninha, 25: 513-520.

Correia MN, Camilo EH \& Santos EA (2013) Sulfentrazone efficiency on Ipomoea hederifolia and Ipomoea quamoclit as influenced by rain and sugarcane straw. Planta Daninha, 31:165174

Cunha AR \& Martins D (2009) Classificação climática para os municípios de Botucatu e São Manuel, SP. Irriga, 14:1-11.

Dayan FE, Weete JD, Duke SO \& Hancock HG (1997) Soybean (Glycine max) cultivar diferences in response to sulfentrazone. Weed Science, 45:634-641.

Heap I (2020) The International Survey of Herbicide Resistant Weeds. Available at: www.weedscience.org. Accessed on: January $29^{\text {th }}, 2020$.

Jaremtchuk CC, Constantin J, Oliveira Jr RS, Alonso DG, Arantes JGZ, Biffe DF \& Cavalieri SD (2009) Residual effect of flumioxazin on weed emergence in soils of distinct textures. Planta Daninha, 27:191-196.

Kent LM, Barrentine WL \& Wills GD (1988) Response of twenty determinate soybean (Gycine max) cultivars to imazaquin. Proceedings of the southern weed science society, 41:01-11.
Lima DBC, Silva AG, Procópio SO, Barroso ALL, Dan HA, Costa B \& Braz AJBP (2011) Seleção de herbicidas para o controle de plantas voluntárias de soja resistentes ao glyphosate. Revista Brasileira de Herbicidas, 10:01-12.

López-Ovejero RF, Soares DJ, Oliveira WS, Fonseca LB, Berger GU, Soteres JK \& Christoffoleti PJ (2013) Residual herbicides in weed management for glyphosate resistant soybean in Brazil. Planta Daninha, 31:947-59.

Magalhães CEO, Ronchi CP, Ruas RAA, Silva MAA, Araújo FC \& Almeida WL (2012) Seletividade e controle de plantas daninhas com oxyfluorfen e sulfentrazone na implantação de lavoura de café. Planta Daninha, 30:607-616.

Mahoney KJ, Shropshire C \& Sikkema PH (2014) Weed management in conventional and no-till soybean using flumioxazin/pyroxasulfone. Weed Technology, 28:298-306.

Mancuso MAC, Aires BC, Negrisoli N, Corrêa MR \& Soratto RP (2016) Seletividade e eficiência de herbicidas no controle de plantas daninhas na cultura do feijão-caupi. Revista Ceres, 63:25-32.

Matte WD, Cavalieri SD, Pereira CS, Ikeda FS \& Costa WB (2019) Residual activity of diclosulam applied to soybean on cotton crop in sucession. Planta Daninha, 37:1-11.

Meschede DK, Oliveira Jr RS, Constantin J \& Scapim CA (2004) Período anterior à interferência de plantas daninhas em soja: estudo de caso com baixo estande e testemunhas duplas. Planta Daninha, 22:239-246.

Monquero PA (2014) Aspectos da biologia e manejo das plantas daninhas. São Carlos, Rima. 434p.

Monquero PA, Munhoz WS \& Hirata ACS (2013) Persistência de imazaquim e diclosulam em função da umidade do solo. Revista Agro@mbiente, 3:331-337.

Muller TC, Boswell BW, Mueller SS \& Steckel LE (2017) Dissipation of fomesafen, saflufenacil, sulfentrazone, and flumioxazin from a tennessee soil under filed conditions. Weed Science, 62:664-671.

Neto MEF, Pitelli RA, Basile EAG \& Timossi PC (2010) Selectivity of post-emergence herbicides applied on genetically modified soybeans. Planta Daninha, 27:345-352.

Oliveira Jr RS, Constantin J \& Inoue MH (2011) Biologia e Manejo de Plantas daninhas. Curitiba, Omnipax. 348p.

Oliveira Neto A, Constantin J, Oliveira Jr RS, Guerra N, Braz GBP, Vilela LM \& Ávila LA (2013) Sistemas de dessecação em áreas de trigo no inverno e atividade residual de herbicidas na soja. Revista Brasileira de Herbicidas, 12:14-22.

Pitelli RA (1985) Interferência de plantas daninhas em culturas agrícolas. Informe Agropecuário, 11:16-27.

Raimondi MA, Oliveira Jr RS, Constantin J, Biffe DF, Arantes JGZ, Franchini LH, Rios FA \& Osipe JB (2010) Residual activity of herbicides applied to the soil in relation to control of four Amaranthus species. Planta Daninha, 28:1073-1085.

Reddy SS, Stahlman PW, Geier PW \& Thompson CR (2012) Weed control and crop safety with premixed s-metolachlor and sulfentrazone in sunflower. American Journal of Plant Sciences, 3:1625-1631.

Rodrigues BN \& Almeida FS (2011) Guia de herbicidas. Londrina, Grafmarque. 764p.

Roman ES, Tosso F \& Marinho JAA (2000) Respostas de cultivares de soja a herbicidas. Revista Brasileira de Herbicidas, 1:133-137.

Sanchotene DM, Dornelles SHB, Bolzan TM, Voss HMG, Escobar OS, Leon CB \& Shimóia EP (2017) Desempenho de diferentes herbicidas pré-emergentes para controle de Euphorbia htererophylla na cultura da soja. Perspectiva Erechim, 41:07-15. 
Silva KS, Freitas FCL, Silveira LM, Linhares CS, Carvalho DR \& Lima MFP (2014) Eficiência de herbicidas para a cultura do feijão-caupi. Planta Daninha, 32:197-205.

Silva AF, Concenço G, Aspiazú I, Ferreira EA, Galon L, Freitas MAM \& Ferreira FA (2011) Período anterior à interferência na cultura da soja-rr em condições de baixa, média e alta infestação. Planta Daninha, 27:57-66

Silva AS, Ferreira EA, Concenço G, Ferreira FA, Aspiazu I, Galon L, Sediyama T \& Silva AA (2008) Densidades de plantas daninhas e épocas de controle sobre os componentes de produção da soja. Planta Daninha, 26:65-81.
Sindiveg (2018) Comercialização de defensivos agrícolas no Brasil em 2018. Available at: https://sindiveg.org.br/estatisticasdo-setor/. Accessed on: December 9 9 $^{\text {th }} 2019$.

Velini ED, Frederico LAM, Morelli JL \& Marubauyashi OM (1993) Avaliação dos efeitos do herbicida clomazone, aplicado em pós emergência inicial, sobre o crescimento e produtividade de soqueira de cana de açúcar (Saccharum officinarum cv. SP 711406). Stab, 12:30-36.

Walsh KD, Soltani N, Hooker DC, Nurse RE \& Sikkema PH (2015) Biologically effective rate of sulfentrazone applied preemergence in soybean. Canadian Journal Plant Science, 95:339344. 